UNANI PERSPECTIVE OF OLIGOMENORRHOEA: AN UPDATED LITERARY RESEARCH

\title{
Paediatrics
}

\section{Dr. Nasreen}

Aklaque

Prof. Wajeeha
Begum

Assistant Professor, Department of Paediatrics, SUMC, Prayagraj,Uttar Pradesh.

Professor\& HOD, Department of Obstetrics \& Gynaecology, NIUM, Bengaluru,

Karnataka

\section{ABSTRACT}

Infrequent and scanty menstruation is a common problem in women belonging to reproductive age group. Oligomenorrhoea affects $6-18 \%$ of women of reproductive age and is mostly managed by hormone therapy which has got its own side effects. One of the most influential Iranian physician, Avicenna (980-1037 A.D.) in his famous book, Canon of medicine, describes oligomenorrhoea under the title of ihtibas-i-tamth. According to USM, normal menstruation is an indicator of healthy normal reproductive organs. One of the main function of the uterus is to excrete the khün-i-hayd (menstrual blood) which should be normal in amount and duration. Any kind of imbalance between quwwat-i-masika (retentive faculty) and quwwat-i-dafi'a (expulsive faculty) of rahim (uterus) causes menstrual irregularities. It is caused by domination of khilt balgham (phlegm) which increases the viscosity of blood. Majoosi stated the cause of qillat-i-tamth is su'i-mizäj bārid of rahim (cold temperament of uterus) and siman mufrit (obesity). Unani physicians have given a line of management based on correction of temperament, menstrual regulation by regimental therapies and emmenagogue drugs.

\section{KEYWORDS}

ihtibas-i-tamth, khilt balgham, khün-i-hayd, oligomeorrhoea and su'i-mizāj bārid.

\section{INTRODUCTION:}

In classical unani text oligomenorrhoea is mentioned under the heading of Ihtibas-i-tamth or Qillat-i-tamth. ${ }^{1,2}$ Unani physicians has given opinion that if menstruation is normal in duration, quality and quantity, it shows the woman is healthy. It occurs once in a month that helps in elimination of morbid material from body which is not beneficial. ${ }^{1,3}$ According to Sahib Kaamil the minimum age of menarche is 10 years and maximum is 14 years also added that minimum age of menopause is 36 years and maximum is 60 years. Duration of flow considered minimum when lasts for 1-2 days and maximum for seven days. If the duration between 2 cycles is more than 2 months then it is known as Qillat-i-tamth or ihtibas-itamth $^{1,4,5}$

\section{FACULTIES OF UTERUS (Quwwat-i-rahim):}

Uterus possesses four types of faculties for normal physiological functions:

1. Absorptive faculty $(Q u w w a t-i-j a \bar{a} h i b a)$

2. Recalling faculty (Quwwat-i- häfiza)

3. Retentive faculty (Quwwat-i-māsika)

4. Expulsive faculty (Quwwat-i-dafi'a)

Among the four quwa, quwwat-i-dafi'a is mainly concerned with expulsion of fuzla (menstrual blood). Any abnormal functioning of this quwa is mainly responsible for qillat-i-tamth.

\section{ETIOPATHOGENESIS (Asbāb):}

Unani system of medicine is based on the concept of balancing body humors $(k h i l t)$. Their imbalance causes disease where restoration causes health. ${ }^{1,3}$ Ibn Sina has mentioned: "If the menstrual blood is mu'tadil (balanced) in quality and quantity and the cycles are regular, it preserves health and prevents from diseases. ${ }^{3}$ Qillat-i-tamth is either due to the causes pertaining to the uterus (Asbāb khās-i-Rahim) or due to diseases of other organs (A'da-i-mushärikat).

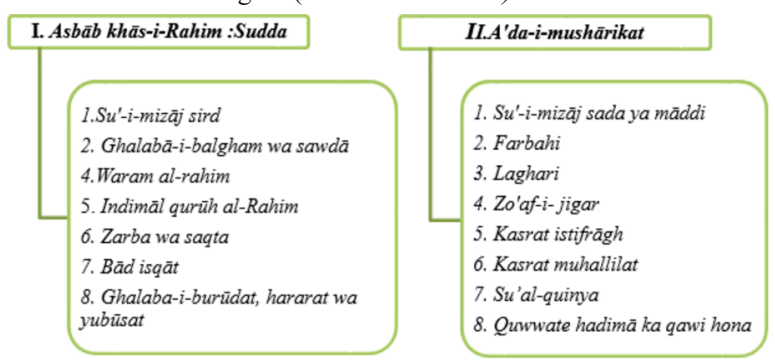

Fig.1 Asbāb qillat-i-tamth ${ }^{25}$

\section{SYMPTOMS (Alamāt):}

4.1. General symptoms ( $A^{\prime}$ 'am alamät):

Headache, loss of appetite, nausea, vomiting, changing color of face, dysuria, low backache, ${ }^{1,6}$ palpitation, indigestion, constipation, heaviness in the body, low urine output, high colored urine, excessive sleep, tiredness, ${ }^{1,3,4}$ heaviness in lower abdomen, groin pain etc. ${ }^{7,8}$

\subsection{Specific symptoms (Khusūsi alamāt):}

4.2.1. Obstructions (Sudda): Menses stops gradually, feeling of heaviness in the body, abdominal distension due to flatulence and change in skin colour.

\subsubsection{Bad temperament $\left(S u^{\prime}-i-m i z a \overline{a j}\right)$ :}

Hotness (Harārat): In case of excessive harārat; signs of waram along with this dryness (khushki) of rahim will be present. ${ }^{3}$

Coldness (Burüdat): Excessive burüdat leads to deep sleep, pallor, perspiration, indigestion, polyuria, phlegmatic stools along with this nabdmutafāwit.,

Dryness (Yubūsat): Dominancy of yubūsat causes malaise, lethargy, veins inconspicuous, together with other features of yubūsat. ${ }^{3,9,10}$

4.2.3. Dominancy of Phlegm and Black bile (Ghalaba-i-balgham and $\boldsymbol{s a w d} \overline{\boldsymbol{a}}$ ): Patient will be obese, puffy and flabby body, cold skin, ${ }^{1}$ pale face, ${ }^{4,11}$ nabd Batī and mutafawit, bawl-sufaid, barāz balghami ${ }^{3,4}$ and scanty pubic hair.,

\subsubsection{Metritis (Warm al-rahim):}

Acute $(\boldsymbol{H} \bar{a} \boldsymbol{d})$ : High fever, backache, pain in the lions, groins and suprapubic region, dysuria, ${ }^{30}$ bitter taste of mouth, tongue coated together with; tachycardia and tachypnoea.

Chronic (Muzmin): Heaviness in pelvis, difficulty in micturition and defaecation and abdominal distension like ascites. ${ }^{4,10}$

4.2.5. Diseased Liver (Zo'af-i-jigar): Poor appetite, lethargy, right hypochondric pain especially after meals, pallor and oedematous face, thready pulse, urine-viscous, blood stain stools."

4.2.6. Anaemia (Su'al-quinya): Previous history of starvation, exertion, heavy work along with lethargy, malaise and icterus. ${ }^{10}$

5. DIAGNOSIS (Tashkhees): It is based on clinical presentation of the patient.

- Ibn Sina states that when blood goes towards the uterus and if it 
does not find the way to escape out from the body; it will return back to the body, and when this process is repeated several times, it results in complications such as sayalān al-rahim (Leucorrhoea), waram al-sulb (metritis), uqr (infertility), ${ }^{7,81}$ warm al-jigar (hepatitis)and istisqā (ascites) etc. ${ }^{1,2,4}$

- Hippocrates mentioned, "women whose menstruation is less than three days or is robust with masculine appearance; they will not become pregnant." He was aware of connection between oligomenorrhoea, obesity, hirsutism and infertility. ${ }^{4}$

- Uqr (Infertlity): Su'i-mizāj bārid causes uterine vasoconstriction $\&$ spasm of fallopian tubes so that nutfa (gamete) fails to reach the uterus. Ibn Sina states that su'i-mizäj ratab results in infertility due to zo'af-i-quwwate jadiba and māsika of uterus, which leads to decrease endometrial receptivity and failure of embryonic implantation. 3,14

- Marz ikyās khusyaturrahim (PCOD): Su'i-mizāj bārid of the liver leads to abnormal production of balgham, as liver is unable to convert chyme into blood, instead it converts it into balgham-ilazuj which accumulates in sacs to form cysts. Hence, dominance of khilt-i-balgham in the body leads to amenorrhoea and cyst formation in ovaries. ${ }^{15}$

- Hirsutism: It is mentioned as a complication of prolonged amenorrhoea associated with other masculine features like hoarseness of voice and male body contour. ${ }^{1,4,16}$

- Ismail Jurjani explained the cause of hirsutism as variation in normal temperament of women. If oligomenorrhoea persists for long duration, the temperament gets transformed towards that of men, ${ }^{3,15}$ which is mainly due to ihtirā $q$ of balgham to sawdā leading to excessive hair growth over body and hyper pigmentation (acanthosis nigricans). ${ }^{11,15}$

\section{LINE OFTREATMENT (Usül-i-'iläj):}

\section{- Treat the cause}

- Idrār-i-hayd with use of mudirr-i-hayd drugs.

- Ta'dil-i-mizāj with use of mundij wa mushil-i-balgham advia.,

\section{TREATMENT ('Ilaj):}

- The treatment regimen can be divided into four steps.

I. Ilaj bi'l-tadbìr (Regimenal therapy)

ii. Ilaj bi'l-ghida (Dietotherapy)

iii. Ilaj bi'l-dawa $\bar{a}$ (Pharmacotherapy)

iv. Ilaj bi'l-yad (Surgical treatment) ${ }^{1}$

\section{(i). Regimenal therapy ('Ilaj bi'l-tadbīr):}

- Riyādat: Riyādat-i-qawi to reduce body weight, Muhallil varzish and counselling should be considered together with moderation of activities. $^{1}$

- Dalk: Massage with Natrūn or zift balūt followed by hammām can reduce fat accumulation. ${ }^{11}$

- Hammām-i-yābis: It is recommended in obese women. It should be done before taking meals and after the procedure, advice to sleep for some time, then take small quantity of food. ${ }^{9,14}$

- Takmīd: Takmīd at lower abdomen with hār advia mainly advia-imuhammira as it stimulates blood flow towards the uterus.

- Ábzan: Powdered rāi is mixed in hot water in a tub and then patient is asked to sit in this for 10-15 mints daily. ${ }^{8}$

- Firzaja: According to Jalinoos powdered kutki siyāh along with indrayen doughed in water used as firzaja. ${ }^{18}$

- Istifräghät: In case of obesity measures should be taken to stimulate Harārat Gharīziyya by advising purgatives 2-4 days before menstruation. ${ }^{8}$

\section{Hijāma bi'l shart (wet Cupping) :}

Application of hijāma over the calf muscles is more beneficial to induce menstruation. In obese and robust women having narrow uterine vessels venesection fails to evacuate the sufficient amount of blood but the cupping does, as it purifies the blood.

Common sites: Calves, two medium size cups are applied over the calf muscles \& 8-10 incisions up to a depth of 2-3 mm are given with sterile blade (no 11) and time required for the procedure is 5-10 minuts.

Other sites: Ankle, pelvis \& adjacent organs. ${ }^{19}$

Principles: Hijäma works on the principle of tanqiya-i-mawād and imāla mawād. It removes the toxic blood from the body, thus it detoxify the body. ${ }^{20,21}$
Time of application: 2 or 3 days prior to the expected date of menstruation on one day on one calf followed by its application on next day on second calf.

Benefits: Cupping of calf muscles is similar to venesection of saphenous vein; as it eliminates more blood because the calf muscles are the lower dependent part and mawäd in normal condition has a tendency to flow towards the lower part of the body and the same can be sucked out with cupping. ${ }^{19}$

- Hamūl: Flour of turmus along with pudina and honey. ${ }^{11}$

- Shiyäf: According to Jalinoos shiyāf made with farfiyūn induces menstruation instantly. ${ }^{18}$

- Dimād:

> Application of joshānda of hār and mulattif advia over lower abdomen.

> Apply paste of tukhm bedanjīr or biranjāsif over suprapubic region.

\section{(ii). Dietotherapy ('Ilāj bi'l ghidā):}

Treatment of the diseased condition by rectifying the asbāb sittah zarūria and ghair zarūria, ${ }^{3,17}$ together with managing the quality of food. ${ }^{17}$ It may be withheld, reduced or given in a moderate quantity or purposely increased. Diet change may be qualitative, quantitative or both.

\section{(iii). Pharmacotherapy ('Iläj bi'l-dawāa):}

The principle of treatment in unani system of medicine is 'iläj bi'l zid; the temperament of disease being bārid ratb, the drugs having hār yābis mizāj; possessing the properties of mudirr-i-hayd, mulattif balgham and mufattih are used in the treatment of qillat-i-tamth. ${ }^{23}$

\section{Mechanism of action of mudirr-i-hayd advia:}

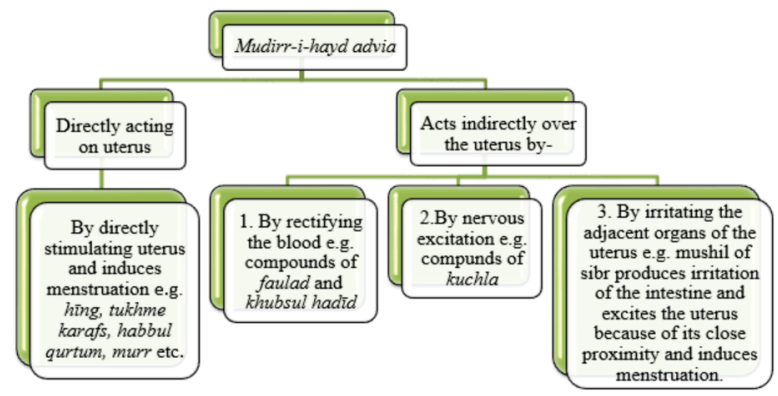

Fig.2: Mechanism of action of mudirr-i-hayd advia ${ }^{17}$

\section{Qawi mudirr-i-hayd advia:}

Oral use:

- Decoction of Hiltīt and murr along with filfil. ${ }^{11}$

- Prepare tablet of muqil, murr and abhal in equal quantity and use in a dose of $10.5 \mathrm{~g}$.

- Decoction of shonīz, nānkhua, qardmāna in dose of 130gm is used daily before menstruation.

\section{(iv). Surgical treatment ('Ilāj bi'l-yad):}

Mainly it includes fasād (venesection) which helps in stimulating menstruation. Fasād is beneficial, if not contraindicated otherwise. It should be done 2 days before menstruation. Mainly the fasād of rag-i$s \bar{a} f i n$ (saphenous vein) \& fasād of mabiz (popliteal vein) is done. ${ }^{1,2}$

\section{CONCLUSION:}

According to unani medicine, normal menstruation is an indicator of healthy normal reproductive organs. In classical unani literature Qillat-i-tamth i.e. a spectrum of condition varying from scanty flow to menstruation occurring at an interval of more than 2 months. Hippocrates mentioned the main cause of disease is impairment of humors (akhlāt), he believes that it is necessary to treat the patients with oligomenorrhoea to avoid complications.

\section{REFERENCES:}

1. Jurjani AH. Zakheera Khawarzam Shahi (Urdu translation by Khan HH). New Delhi: Idarae Kitabul Shifa;2010:220-25,590-91,598-602.

2. Baghdadi IH. Kitabul Mukhtaraat Fil Tibb (Urdu translation by CCRUM).Vol.IV.New Delhi:CCRUM;2007:13,31-35,112,124-25.

3. Sina I. Al Qanoon Fil Tib. Vol II (urdu trans. by Kantoori GH) New Delhi: Idarae kitabus shifa;2003:1097-98,1445-47

4. Khan A. Al-Akseer (Urdu translation by Kabeeruddin).Vol II.New Delhi: Ejaz publishing house;2011:798-801.

Rushd I. Kitabul Kulliyat. 2nd ed. New Delhi:CCRUM;1987:114,116-17,158-59. 
6. Zuhar I. Kitabul Taiseer Fil Mudawat wa Tadbeer. 1st ed.New Delhi:CCRUM;1986: 185

Jeelani G. Makhzan ul Hikmat.Part-II. New Delhi:Ejaz publication;1996:777-81.

8. Khan HA. Haziq. Karachi: Madina Publishing company; 1983:467-71

9. Chandpuri K. Moajzal Qanoon. New Delhi: Qawmi Council Barae Farogh Urdu Zaban; 1998:382,384,391,459-60

10. Arzani A. Tibbe Akbar. Deoband: Faisal Publication;1903:602-04

11. Razi ABZ. Al-Hawi Fil Tib. Vol IX. New Delhi:CCRUM;2001:151-68

12. Tabri AR. Firdausul Hikmat (Urdu translation by Shah MA). New Delhi: Idarae Kiatabul Shifa;2010:61,254-57,261-62.

13. Tabri AHAM. Al Moalijatul Bukhratia. Vol III. New Delhi:CCRUM; YNM: 318-19.

14. Majoosi ABA. Kamilus Sana (Urdu trans. by Kantoori GH) Vol I. New Delhi: Idarae Kitabul Shifa;2010:249,533-34,538-39.

15. Firdose KF, Shameem I. An approach to the management of poly cystic ovarian disease in Unani system of medicine: A review. International Journal of Applied Research 2016;2(6):585-90

16. Mirza S, Naaz SA, Alim SM. Management of polycystic ovarian syndrome (Keesa-eKhusyatur Rehm): Unani perspective. Am J Pharm Health Res. 2016; 4(1):24-45.

17. Hamdani KH. Usoole Tibb. 2nd Ed. New Delhi: Qaumi Council Barae Farogh Urdu Zuban;2006:331-32,409,473-75,485-86.

18. Shah HM. The General Principles of Avicenna's Canon of Medicine. New Delhi: Idarae Kitabul Shifa;2007:406-8,429-36

19. Shameem I, Parveen R, Saba K, Athar M. An Updated Review of Efficacy of Cupping Therapy in Gynecological Disorders. Journal of Dental and Medical Sciences Nov 2017;16(11):38-45.

20. Begum W. Treatment of polycystic ovarian syndrome by wet cupping-a case report and review of literature. Journal of Ayurveda and Holistic Medicine (JAHM) $2015 \mathrm{Jul}$ 9;3(3):41-5.

21. Ahmed KR. Tarjuma wa Share Kulliyate Qanoon. New Delhi: Kamal printing press; 1945:346-49.

22. Kabeeruddin M. Bayaze Kabeer. New Delhi: Idarae Kitabul Shifa;2010:207-8

23. Firdose KF, Begum W, Shameem I. Clinical evaluation of Qillate tams \& its management with Unani formulation. International Research Journal of Medical sciences 2013 Dec $; 1(11): 1-8$ 